\title{
Implementation of work safety permit as an effort to prevent accidents at PT petrokimia gresik
}

\author{
Amarin Yudhana \\ Stikes Surya Mitra Husada Kediri \\ amarinyudhanae8@gmail.com
}

\begin{abstract}
Implementation Safety permit to be used as a form of worker control in performing high-risk jobs to suppress the risk of workplace accidents. The manufacturing sector is one of the many business sectors are classified as very susceptible to accidents. The causes of workplace accidents in the manufacturing sector, among others, the behavior of workers who are less likely to heed the provisions of safety standards. The purpose of this study was to investigate the application of safety permit as part of efforts to prevent workplace accidents in PT Petrokimia Gresik. The study design was the descriptive qualitative approach. The data collection technique was obtained by in-depth interview, using snowball sampling technique informant obtained a total of 11 people. The application of research results safety permit in mind that almost all the safety permit application made in accordance duties and responsibilities of each informant, ranging from the provision of safety permit form, fill, and validation, the process involved is requesting services unit and the unit executing the work. Controlling carried out by safety inspectors, and to validate the safety closure permit carried back by the service requester unit and the unit executing the work. In the validation process of opening and closing, safety inspector involved as a party to verify the safety permit.This study shows that the application of the safety permit has been running well and by the procedures due to the function of safety work permit is a mandatory driver's license issued in any risky job.
\end{abstract}

Keywords: safety permit, the risk of accidents

\section{INTRODUCTION}

In the era of globalization and the free market of the WTO and the GATT, which will take effect in 2020, Health and Safety Environment (HSE) is one of the prerequisites set out in the economic relations of trade in goods and services among countries that must be met by all member countries, including Indonesia. Health and Safety Environment (HSE) can not be separated by the process of both services and industrial production. Development progress after Indonesia's independence leads to consequences resulting increase labor intensity is increasing the risk of accidents in the workplace.

It also resulted in an increased demand higher in preventing accidents of diverse shape and type of accident. Correspondingly, the development of the construction carried out the then drafted UU No.14 in 1969 on the most important points regarding further labor transformed into UU No. 12 in 2003 on manpower. In Article 86 of UU No.13 in 2003, stated that every worker or workers have the right to the protection of health and safety, morals and decency, and treatment by the inherent dignity and religious values.

Problems Occupational Health and Safety (HSE) is generally in Indonesia is still neglected. This is evidenced by the number of accidents is still high, and the level of awareness of the business community on safety is still low. In 2007 the number of accidents recorded fatality rate amounted to 83714 by 1883 (PT Jamsostek, 2007). In 2013 recorded the number of accidents with a fatality rate of as much as 10010626416 (Central Bureau of Statistics).

To anticipate these problems, the Government issued statutory laws and regulations in the field of occupational safety and health as a replacement for the previous regulations Regiment Veiligheids, St 406 in 1910 which was considered inadequate to face the progress and developments. The regulation is UU Number 1 in 1970 on the safety of work scope includes any work environment, whether on land, in the soil, surface water, in the water or air, which is within the jurisdiction of the Republic of Indonesia. The law also regulates safety requirements starting from the planning, manufacturing, transportation, distribution, trade, installation, usage, use, maintenance and storage of materials, goods and technical products production apparatus containing and may pose a hazard.

The manufacturing sector is one of the many areas that are categorized as highly vulnerable to accidents as in [1]. Factors causing accidents in the sectors of manufacturing, among others, the behavior of workers who tend to lack the provisions of safety standards, the selection of work methods that are less precise, changes in the workplace, the equipment used and the factor of lack of discipline of the workforce in comply with the provisions of the Occupational Safety and Health Environment (HSE), which among other things regulates the use of Personal Protective Equipment (PPE) as in [2] Of the factors that cause the occurrence of work accidents as mentioned, indicate that workplace accidents occur more commonly caused by human error (human error), both from the aspect of the competence of the executive as well as understanding the importance of the implementation of Occupational Health and Safety Environment (HSE).

PT PKG is one of the sectors of manufacturing enterprises engaged in the production of fertilizer and nonfertilizer and chemicals that support the manufacturing process. 
PT PKG put safety and health environment of the management system (SMHSE) as the main values in the order of company policy and as a supporting line of business which has equal priority with core business line. This is consistent with management's goal to achieve "HSE Excellence" which impact on the achievement of "Operation Excellence." PT PKG has a principle that aspects of the Occupational Health and Safety Environment (HSE) should take precedence in all activities carried out in the region of PT PKG to protect workers, assets, processes, and the environment from accidents that can cause harm. HSE program carried out in conjunction with the production, done effectively and efficiently as possible, so it will not interfere with production activities if possible. All officials working in the PT PKG is responsible for compliance with the regulations Occupational Safety and Health Environment (HSE) prevailing in the PT PKG and is responsible for the safety of every worker under his supervision. Officials at PT PKG has the authority to stop any work related to PT PKG if found unsafe acts (unsafe action) or unsafe conditions (unsafe condition) as well as on the job is expected to be an accident that affected the occurrence of a loss in workers and companies. When working in the area of PT PKG, workers are required to adhere Golden Safety Rules PT Petrochemical Gresik which includes traffic safety (traffic safety), work at height (work at height), work in confined spaces (confined space work), personal protective equipment ( personal protective equipment) and the work of bearing (lifting operation) [3].

In suppressing the risk of accidents PT PKG implement a Safety Permit system as one effort or form of worker control in doing high-risk work, such as working at height, electricity, space is limited, and excavations more than 1.8 meters. Recapitulation data usage of Safety Permit 5 past five months in the area of production of the two as much as 5502 Safety Permit, the production area as much as in 2181 and three production regions as 5393. Thus the production of the two is the production area to the level of use of Safety Permit most especially combined. Safety is a Safety Permit combination that has the same hazard assessment, e.g., disconnect pipe work and work in the tank/vessel/boiler. Two production units in addition to producing fertilizers as well as technical and operational units so that exposure to the hazard more often. Dangers in two production units are mechanical hazards associated with the appliance, the state apparatus and machines move.

Application of Safety Permit PT PKG seen from the procedure very well but implementation on the ground is not by procedures such as the use of Personal Protective Equipment Self-control by the Safety Inspector, and the implementation of Housekeeping. As in [4]. Besides the lack Safety Inspector in Region II also inhibits the production of Safety Permit appropriate implementation procedures. Application of Safety Permit PT PKG as a means to prevents the occurrence of accidents by UU No. 1 in 1970 on Occupational Safety, the Minister of Manpower No. Per/05/Men/1996 on Management System HSE, and HSE Handbook.
Based on the above background, the researcher interested to study about the implementation of Safety Permit and procedure from start to finish with the title: "Application of Safety Permit For One Effort to Prevent Accidents in PT PKG

\section{METHOD}

Judging from the data type of the research approach used in this study is a qualitative approach. As in [5] This type of research is descriptive qualitative research focus is directed to determine the application of Safety Permit as an effort to prevent occupational accidents in depth. The subject of this research is the whole all workers/safety representative in the production 2B gain Safety Permit, all safety inspector and the entire unit requesting services. Informants in this study are some workers/safety representative who received the Safety Permit are willing to in-depth interviews (in-depth interview), the entire safety inspector and a unit of the service requester, the overall total of 11 people. Sampling techniques in this study using snowball sampling. As in [6]. The instrument used is the researchers themselves and interview guides whose contents are questions about the application of the safety permit. Data processing in this study includes Reduction of data, display data, the inference/Verification. One technique authenticity of data is to use triangulation techniques

\section{RESULTS}

Characteristics Informants from the results of research conducted by the snowball sampling technique gained 5 short information. Description of 5 informants are as follows: Informant 1 , has been working for more than 8 years. He said that every day he always obtain a safety permit from the requesting unit and verification services in the office of safety. Not knowing the safety procedures permit and fill out a checklist corresponding service requesting unit. Informant 2, has been working for 10 years and is a substitute safety. He said that every day always gets a safety permit from the requesting unit and verification services in the office of safety. Not knowing the safety procedures permit and fill out a checklist is loaded by the requesting unit services. Informant 3, has been working for 10 years. He said that every day he always obtain a safety permit and perform verification at the office of safety. Not knowing the safety procedures permit and fill out a checklist according to the service requester unit.. The informant 4 , has been working for more than 8 years. He said that every day he always obtain a safety permit and verification is done in the field for a 24-hour job for dewatering tank Phosphoric Acid. Work has been done before obtaining verification of a safety inspector for draining the tank is a 24hour job and continue for approximately 2 weeks. So every day there is always a safety control inspector. Did not understand the safety procedures permit and fill out a checklist by what is needed. The informant 5, has been working for 9 years. He said that every day always gets a safety permit and verification carried out in the control room. The work is not done by a third 
party and approved by the local unit so work can already be implemented and the safety inspector can verify when controlling.

\section{Trianggulasi Research}

The results of interviews conducted on KASI triangulation related to the implementation of safety permit to PT PKG:

a. Are any service requester unit began work always publish safety permit? Yes, yes, every day, every time there is a job, both regular maintenance and repair, safety permit always we publish" (informant 1) "Yes clearly, if we have a work area yes safety permit we always provide " Yes clearly, if we have a work area safety permit we always provide "(informan 2)

b. How charging safety permit? Whether checking/security area before publishing? "A. Yes we are unit area/chargers request this general data, then the service request column, anything that is necessary and not in accordance with the work, keep the Personal Protective Equipment. After that the unit implementing our work order filling the column of the implementing unit. I've signed in here. Checking is always our area, have memorized. For example this work in this area, oh so immediately already know "(informant 1). "Today we have cleaning jobs, so this is written aspect of his work, then checklist filled in as required, our service request column that fills in the work done in this area. If the required gas checks are done first is to report to the safety inspector. After that for APD the personal protective equipment used by the worker we will specify. For checking done every day because we also look to the field. 2).

c. How attestation of a safety permit? " Through the signature of the area owner/unit requesting the same unit work unit. After that, the safety clearance will be brought to the office for the signature to the safety inspector "(informant 1). "Yes, I will need signature after that the executor of the activity will signature, and we get permission to work directly. Sometimes there is also brought to the safety office to ask for a signature to the safety inspector or when the safety of his tour will be signed "(informant 2)

d. Is there always a safety control inspector? " yes obviously, we are always around to control" (informant 1). "We are usually around to check and ask for safety permit signatures that have not been signed" (informant 2)

e. The circumstances permit ratification of safety closures? An evaluation and housekeeping not? "Usually if the job has finished its safety workers are here to ask for autographs. Sometimes we check sometimes yes we make sure by asking to his safety. After that I sign, the executing unit is also the signature. If it will be requested signature to the safety office. "(Informant 1)

"When the work is done will be checked and will be signed and declared completed. Then the signature will be requested to the safety inspector. "(Informant 2)

\section{DISCUSSION}

Risk of Accidents in PT PKG based on the research that the job has risks of accidents at PT PKG that work with hot (P), Jobs entered the tank/drum/reactor/boiler (MV), Work at height potential fall (KTG), Work in the acid/alkali ( A), Work in the area of flammable (MT), Work in the area of explosive (MM), Employment disconnected pipe, vessel (MP), Employment excavate the ground (G), Work in the area of high voltage (L), work at heights with the help of a crane (C).

By the safety production permit $2 \mathrm{~B}$ PT PKG, the risk of accidents includes falling, slipping, falling, fire, slipped and exploded. Accidents can occur because of the condition of the tool or material adverse or dangerous as in [7]. Accidents can also be caused by environmental conditions unsafe work. Additionally accidents can also be derived from human activities in the workplace and handle tools or materials as in [8].

The risk of accidents PT PKG namely fire and explosion due to the PT PKG is a gas-based fertilizer industry. Also negligence of the workers is also a risk of accidents due to lack of safety awareness on himself. Ignoring safety on the basis of work already common and uneven control makes workers indifferent and convenience of using personal protective equipment due to not accustomed also makes the work of breaking the rules. As in [9].

\section{Application of Safety Permit PT PKG}

1. Provision of Safety Permit Form, fill, and ratification of Work Safety Permit (safety permit).

Field observations and interviews that are provided in the form of safety permit the requesting unit services, safety office, control room, maintenance unit/unit instead of the contractor executing the work units requiring a safety permit form. Safety permit issued by the requesting unit services in accordance with the existing work order. Permit Form Safety (Safety Permit) is provided by the unit requesting the service, at the Department of Production and every space observer, the Department of Maintenance, Infrastructure Plant \& Region, and other Department of need. Ref [10] This was revealed by five informants as a safety representative that every day they get a safety permit from the service requester unit/unit area. Thus the service requester unit/unit area provides a form of safety permit.

2. Form Filling Safety Permit

From the results of observational studies in the field of safety and permit interviews that form filled out by the requesting unit of service/unit area that includes general data, checking the area of the column unit and the service requester checklist Personal protective equipment must be used in accordance with the type of job workers. Column unit for executing the work completed by the worker, if the work performed by the third party/contractor then the safety representative responsible for filling out the form of safety permit. Before filling the form of safety permit checking area by the service requester unit/unit area and unit executing the work to ensure that the area is already $d$ 
bagged. When the service requester unit and the unit executing the work already done by the attestation of safety permit sign form then the form of safety permit was taken to the office of safety to service requester unit and the unit executing the work already done by the attestation of safety permit sign form then the form of safety permit was taken to the office of safety to be verified by the safety inspector and filling the daily attendance permit. Work can already be started or carried out only with the consent of the service requester unit and the unit executing the work, but the safety permit must still be verified by the safety inspector before expiry permit runs out. Filling in the form of safety permit was in accordance with the applicable procedures. However, there are still some that do not fit. In the field found that there is a safety representative where safety permit form is filled entirely by the service requester unit due to a work order issued by the service requester unit /unit area and the work carried out in the unit area. In accordance with that expressed by the informant 2 and the informant 5 as a safety representative. There is also a safety representative who does not know the type of protective equipment listed and must be used in the form of safety permit.

3. Endorsement Form Safety Permit

From the research, field observations and interviews that the ratification of the safety permit, namely by signing the form of safety permit in the column that has been provided to the requesting unit and the services unit executing the work. Signer safety permit constituted by checking/ security work area. Ratification of the safety permit already done, according to existing procedures, it was revealed by the informant 1,3,4 and 5 as a safety representative, and it also strengthened the interview by triangulation is KASI who said that the service requester unit/unit area fill in the general data, the service requester unit checklist and a list of personal protective equipment and for executing the work unit column filled by the safety representative as a third party. However, the field is still found checks/security area was not carried out by the unit requesting the service/unit area due to work is done every day and already know and understand the work area will do the job, it was revealed by the informant 3 as the unit requesting the service/unit area.

4. Control by Safety Inspector

From the research, observation, and interviews that every day after verifying the safety permit, a safety inspector is always controlling the area around. In addition to checking and supervision of workers and work safety inspector also verify the safety permit, which has not been verified because the work is not done by a third party/contractor. In controlling the safety, inspector has the right to stop work if a mismatch between the safety permit is obtained to those in the field. Controlling been running well and do every day that disclosed by all informants as a safety representative and reinforced the results of interviews with triangulation which KASI, but not all work can be covered by controlling a safety inspector is due to the limitations of safety and efficiency. This was revealed by the whole safety inspector who became an informant.

5. Closing Safety Permit

From the research, observation and interviews that the safety closure permit on the basis of a good area checking tools is used, the work has been completed and the cleanliness of the area. if everything had been done and the work is completed the service requester unit/unit area and unit executing the work permit signed a safety closure in the available space. And then taken to the safety office for verification.

From the research carried out showed that the application of the safety permit to PT Petrochemicals of provision from a safety permit, filling and inspection area, the endorsement opening safety permit, control until the closing of the attestation of safety permit goes well in accordance with the procedure, although the reality on the ground is still found a discrepancy the overall implementation of safety permit can already be used as a tool to minimize accidents

\section{CONCLUSIONS}

Work that has a risk of accidents among others Works with heat (P), Jobs entered the tank/drum/reactor/boiler (MV), Work at height potential fall (KTG), Work in the acid/alkali (A), Jobs regional flammable (MT), Work in the area of explosive (MM), Employment disconnected pipe, vessel (MP), Employment excavate the ground $(\mathrm{G})$, Work in the area of high voltage (L), work at heights with the help of a crane (C).

The risk of workplace accidents in PT PKG is falling, slipping, falling, fire slipped, and exploded. Based on the findings that Provision of safety permit forms provided by the requesting unit services, office safety. Filling in the form of safety permit made by the requesting unit that includes a common data services, field checks/inspection service requesters, as well as Personal Protective Equipment checklist. As for the column unit executing the work completed by the employee and if the work is done by a third party/contractor the safety permit required by the safety representative. As in [11].

Ratification of the safety permit is done by signing the form of safety permit by the service requester unit/unit area and work with the basic implementation unit have been checking / inspection/security area. And then verified by the safety inspector.

Control by safety inspector is always done with the purpose of surveillance of workers with the work by a safety permit already issued before the work and safety of the workers. If there are discrepancies or violations in the field of safety inspector is entitled to stop the work. e. Closing safety permit did by signing the form of safety permit by the service requester unit/unit area and unit executing the work by re-examination of the work area both tools are used, the cleanliness of the area and the work itself or have been evaluated and housekeeping. And then verified by the safety inspector. 
Application of safety permit to PT Petrochemical has been going well and according to the procedure, but not maximized due to the negligence of workers and supervision have not been covering the whole. Nevertheless, the safety permit application can minimize the occurrence of accidents.

\section{REFERENCES}

[1] R. M. Choudhry and D. Fang, "Why operatives engage in unsafe work behavior: Investigating factors on construction sites," vol. 46, no. 4, pp. 566-584, Apr. 2008.

[2] W. I. Ervianto, Alat Pelindung Diri. Yogyakarta: Graha Ilmu, 2005.

[3] Petrokimia., Lampiran Surat Ijin Keselamatan Kerja Gabungan,: FM-300261. Gresik. 2005.

[4] Petrokimia, "Alur Pelaksanaan Surat Ijin Kerja Gabungan,: FM-300261. Gresik," 2014.

[5] S. Notoatmodjo, Metodologi Penelitian Kesehatan. Jakarta: Penerbit Rineke Cipta, 2010.

[6] Sugiyono, Metode Penelitian Kuantitatif. Kualitatif dan R\&D. Bandung: Alfabeta., 2011.

[7] C. Lombardo, B., Eyre, "Scopus - Document details," Online J. Issues Nurs., vol. 16, no. 1, p. 3, 2011.

[8] Permenaker, Permenaker. No. 8 Tahun 2010 tentang APD. 2010.

[9] inani Puspitasari, Analisis Implementasi-Pendahuluan. Jakarta: FKM Universitas Indonesia, 2008.

[10] Petrokimia, Buku Saku HSE. Gresik, 2015.

[11] Peraturan Pemerintah, Peraturan Pemerintah (PP) No. 50 Tahun 2012, Sub Elemen 6.1.5 Terdapat Sistem Ijin Keja Untuk Tugas Berisiko Tinggi. 2012. 